\title{
平成26年度 産業応用部門論文委員会名簿
}

\author{
和 文 論 文 誌 論 文 委 員 会 \\ 編 修 長 森本 雅之（東海大学） \\ 副 編 修 長 寺田 賢治 (徳島大学) \\ D 1 グループ (半導体電力変換) \\ 主查 中沢 洋介（東芝）副主査 三野和明（富士電機） \\ 幹事 伊東 淳一 (長岡技術科学大学) 星 伸一 (東京理科大学) 森實 俊充 (大阪工業大学) \\ 和田 圭二（首都大学東京） \\ D 2 グループ (産業計測制御, メカトロニクス制御) \\ 主查 高橋 悟 (香川大学) 副主査 駒田 諭 (三重大学) \\ 幹事 熱海 武憲 (HG S T ) 内村 裕 (芝浦工業大学) 藤本 博志（東京大学）満倉 靖恵（慶應義塾大学） \\ D 3 グループ (回転機, モータドライブ, リニアドライブ) \\ 主查 樋口 剛 (長崎大学) 副主査 廣塚 功 (中部大学) \\ 幹事 榎本 裕治（日立製作所）坂本 泰明（鉄道総合技術研究所）森下 明平（工学院大学） \\ 山本 吉朗（鹿児島大学）山本 修 (職業能力開発総合大学校) 山本 康弘 (明電舎) \\ D 4 グループ（自動車技術，IＴＳ，家電・民生） \\ 主査 浜松 芳夫（日本大学）副主査 結城 和明（東芝） \\ 幹事 真田 雅之 (大阪府立大学) 高橋 聡 (名古屋電機工業) 宮武 昌史 (上智大学) \\ D 5 グループ (ものブくり, 次世代産業システム, 交通・電気鉄道, スマートファシリティ, 公共施設) \\ 主查 浜松 芳夫 (日本大学) 副主査 結城 和明 (東芝) \\ 幹事 市川 紀充 (工学院大学) 古関 隆章 (東京大学) 鈴木 健嗣 (筑波大学) 山中 理（東芝）
}

編修長 大石 潔（長岡技術科学大学）

\section{英 文 論 文 誌 論 文 委 員 会}

D 6 グループ (Power Electronics and Its Applications)

主查 藤田 英明 (東京工業大学) 副主 查 横山 智紀 (東京電機大学)

幹事 芳賀 仁 (長岡技術科学大学)

D 7 グループ (Motion Control, Robotics, Sensing and their Applications)

主査 藤本 康孝（横浜国立大学）副主査 柴田 昌明（成蹊大学）

幹 事 石川 潤 (東京電機大学) 残間 忠直 (千葉大学)

D 8グループ (Electric Machine, Motor Drive and their Applications)

主查 小坂 卓 (名古屋工業大学) 副主查 久保田 寿夫 (明治大学)

幹事 近藤 圭一郎 (千葉大学) 真田 雅之 (大阪府立大学) 鳥羽 章夫 (富士電機) 